\title{
Pulse shape neutrons and gamma quanta discrimination by means of plastic scintillator of the new generation
}

\author{
P.N.Zhmurin, V.N.Lebedev, A.F.Adadurov, \\ V.N.Pereymak, Yu.A.Gurkalenko \\ Institute of Scintillating Materials, STC "Institute for Single Crystals", \\ National Academy of Sciences of Ukraine, \\ 60 Lenin Ave., 61001 Kharkiv, Ukraine
}

Received June 6, 2013

\begin{abstract}
Plastic scintillator (PS) of the new generation was developed for the pulse shape neutron and $\gamma$-quanta discrimination ( $n / \gamma$-discrimination). To impart $n / \gamma$ discrimination property two activation centers with different decay times were inserted in the PS. One of them transforms singlet excitation into fluorescent light, while the other - makes the same for triplet excitations. 1,4-Dimethyl-9,10-diphenylanthracene and tris(benzoylmethide) (1,10-phenantroline) Europium III - were used as activators. The figure of merit is $\mathbf{1 . 4 8}$ for this scintillator which is sufficient for reliable $n / \gamma$-discrimination.
\end{abstract}

Разработан пластмассовый сцинтиллятор (ПС) нового поколения для разделения нейтронов и гамма-квантов по форме импульса ( $n / \gamma$-разделение). Для придания ПС свойства $n / \gamma$-разделения в него внедрены два активационных центра с различными временами свечения, один из которых преобразует в свет синглетные возбужденные состояния полимерной основы, а второй - преимущественно его триплетные возбужденные состояния. В качестве активаторов синглетных и триплетных возбуждений используются 1,4-диметил-9,10-дифенилантрацен и дибензоилметанфенантролин европия. Получено значение разделяющей способности ПС 1.48 , что является достаточным для надежного $n / \gamma$-разделения.

Пластмасовий сцинтилятор нового покоління для розділення нейтронів гамма-квантів (n/ү-розділення) за формою імпульсу. П.М.Жмурін, В.М.Лебедєв, О.Ф.Ададуров, В.М.Переймак, Ю.А.Гуркаленко.

Розроблено пластмасовий сцинтилятор (ПС) нового покоління для розділення нейтронів і гамма-квантів за формою імпульсу ( $n / \gamma$-розділення). Для надання ПС властивостей $n / \gamma$-розділення, в нього введено два активаційних центра 3 різним часом висвічування, один з котрих перетворює у світло синглетні збудження полімерної основи, а другий - переважно їі триплетні збудженні стани. У якості активаторів синглетних $\mathrm{i}$ триплетних збуджень використано 1,4-диметил-9,10-дифенілантрацен і дибензоілметанфенантролін європію. Отримано значення роздільної здатності ПС 1.48 , що є достатнім для надійного $n / \gamma$-розділення.

\section{Introduction}

A charged particle passing organic medium creates singlet and triplet excited states in different proportions. The number of the excited triplet states significantly depends on ionization energy losses of the particle and therefore on the particle type. So, comparing in some way the population of triplet excited states one can make a conclu- 
sion about the type of particles creating such distribution. The common way to measure such relation is based on observation of, so called, "delayed" luminescence, which is connected with the effect of triplet-triplet annihilation [1]. This effect is clearly observed in liquid scintillators and organic crystals [2-4]. But in plastic scintillators such delayed luminescence is practically absent because lifetime of the excited triplet states of styrene or vinyl toluene chromophore groups under room temperature practically coincides with that of the singlet states [5]. Conventional luminescent additives in plastic scintillators can only collect of the singlet states energy. The reason of this is low spin-orbit interaction which leads to determining of the spin state which forbids the radiationless energy transfer from the states with another spin number. But in metal-organic complexes of heavy metals this forbidding is partially removed because molecular orbitals of these complexes are characterized by the strong spin-orbital interaction which leads to mixing of the states with different spines. It was clearly demonstrated when metal-organic complexes were used in OLE for increasing their efficiency [6].

Therefore, if one creates a polymer base with two optical centers, the luminescence of which is determined by excitation of the singlet states and triplet states of the polymer base, respectively, then it will do possible to create a plastic scintillator which is sensitive to the particles type.

This paper is devoted to study of the plastic scintillator with two luminescent centers which in some measure can register excitation energy of the singlet and triplet states of a polymer base for discrimination of signals from neutrons in the presence of gamma radiation background.

\section{Experimental}

For further investigation, we chose tris(dibenzoylmethide)(1,10-phenanthroline )europium III (Eu[DBM $]_{3}$ Phen)complex as an efficient activator of the triplet excitations. It was used previously as a component of an efficient alpha particle detector $[7,8]$. $\mathrm{Eu}^{3+}$ coordination ion emits at $612 \mathrm{~nm}$ wavelength with $370 \mu$ s lifetime. Singlet energy is also transferred to the complex, but its contribution is less than $25 \%$ because the population of polystyrene triplet levels is three times higher than that of the singlet levels [9]. Thus, the Eu[DBM] $]_{3}$ Phen complex

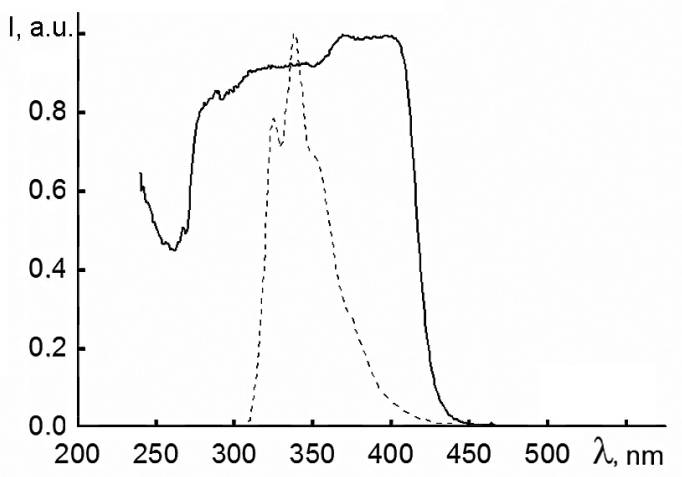

Fig. 1. Excitation spectrum of polystyrene film with 2 wt. $\%$ of $\mathrm{Eu}[\mathrm{DBM}]_{3}$ Phen complex (solid line) and fluorescence spectrum of polystyrene film with 2 wt. $\%$ of $p$-TP (dash line). Observation wavelength $-612 \mathrm{~nm}$; excitation wavelength $-265 \mathrm{~nm}$.

appears to be suitable for slow component of the scintillating pulse formation.

For singlet energy transformation and fast component formation it is obvious to use the same activators that are used in common commercial scintillators. However, our experiments have shown that in scintillating response of polystyrene-based PS (plastic scintillator) with 2 wt. $\%$ of $p$-TP and 2 wt. $\%$ of $E u[D B M]_{3}$ Phen the fast component corresponding to $p$-TP fluorescence is absent, indicating that the $\mathrm{Eu}[\mathrm{DBM}]_{3}$ Phen complex completely quenches the $p$-TP fluorescence. Analogous effect was observed for other known activators-PPO, PBD, etc. To understand the reasons of this quenching we have measured the excitation and fluorescence spectra of two polystyrene films with 2 wt. $\% \quad p$-TP and 2 wt. $\%$ Eu[DBM $]_{3}$ Phen, respectively. Measurements were made using Fluoromax-4 (HORIBA Jobin Yvon Inc., Edison, NJ) spectrofluorometer. The measured spectra are presented in Fig. 1. It is seen that the $p$-TP fluorescence spectrum is totally overlapped with the Eu[DBM] $]_{3}$ Phen absorption spectrum, thus explaining the reason of the observed quenching.

Hence, to solve the problem of $n-\gamma$ discrimination, it is necessary to find an additive whose absorption overlaps polystyrene emission but whose emission lies out of the $\mathrm{Eu}[\mathrm{DBM}]_{3}$ Phen complex absorption. For example, 1,4-dimethyl-9,10-diphenylanthracene (DMDPA) bifluorophore satisfy this requirement.

This compound was obtained according to the method described in [10] with additional purification. The excitation and fluorescence spectra of a polystyrene film with 


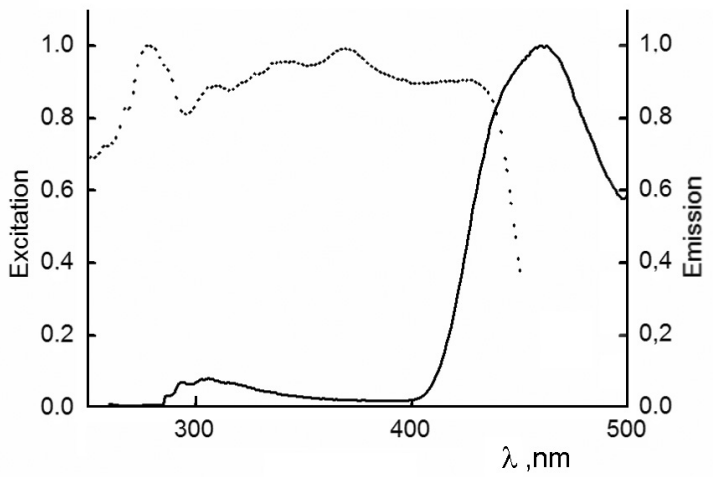

Fig. 2. Excitation and emission spectra of polystyrene film with 1.5 wt. \% of DMDPA. Observation wavelength $-461 \mathrm{~nm}$; excitation wavelength $-265 \mathrm{~nm}$.

1.5 wt. $\%$ DMDPA are presented in Fig. 2. Fluorescence was excited at $265 \mathrm{~nm}$ wavelength (the polystyrene fluorescence maximum). The excitation spectrum was registered at $461 \mathrm{~nm}$ wavelength corresponding to the DMDPA fluorescence maximum.

It is seen in Fig. 2 that the DMDPA fluorescence is located outside the $\mathrm{Eu}[\mathrm{DBM}]_{3}$ Phen excitation band and therefore cannot be quenched by it. Hence, DMDPA bifluorophore can be used as an activator of singlet excitations in PS for $n / \gamma$ discrimination.

Besides the chosen activators, a wavelength shifter was added to the PS, namely,1phenyl-5-(4-methoxyphenyl)-3-(1,8-naftoylene-1', 2'-benzimidazole-4)-2-pyrazoline (L59). It reduces the reabsorption and shifts the DMDPA fluorescence to $598 \mathrm{~nm}$ region, which is close to that of $\mathrm{Eu}[\mathrm{DBM}]_{3}$ Phen (second activator).

PS samples were obtained by means of bulk thermal polymerization in a glass ampoule with further machining. Additives were put in a heat-resistant ampoule, and then fresh distilled styrene was added up to $10 \mathrm{~g}$ of the total mass. To complete the solution of the complex, the ampoule was heated to $35^{\circ} \mathrm{C}$ and blown by argon for 6 min. The ampoule was sealed, placed in a thermostat under $80^{\circ} \mathrm{C}$, and held for $96 \mathrm{~h}$. Then the thermostat was cooled at rate of $5^{\circ} \mathrm{C} / \mathrm{h}$ until it reached $40^{\circ} \mathrm{C}$. The blanks obtained were machined to get transparent polished cylinders (diameter $16 \mathrm{~mm}$; height $10 \mathrm{~mm}$ ).

The parameters of $n / \gamma$ discrimination were measured by a scintillating setup using the Hamamatsu R669 photomultiplier, whose spectral sensitivity is expanded

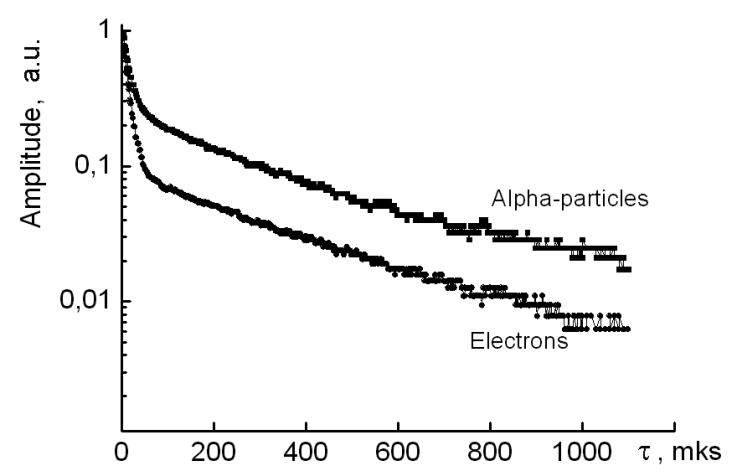

Fig. 3. Normalized decay curves of new PS after irradiation by Pu-239 alpha-particles with $E_{\alpha}=5.4 \mathrm{MeV}$ and of Bi-207 electrons with $E_{e}=0.975 \mathrm{MeV}$.

into the red region. The time constant of the PMT anode signal decay was increased to $\mathrm{RC}=15 \mu \mathrm{s}$ corresponding to $R_{a}=51 \mathrm{k} \Omega$ of the anode load. The PMT signal was applied to both channels of Rigol DC1302 digital oscilloscope. The first channel registered the fast component of the pulse, whereas the second channel registered the slow component. The PS under study had an optical contact with the PMT window and was excited by fast neutrons of plutoniumberyllium source through a lead plate of $10 \mathrm{~mm}$ thickness. Digital oscillograms were collected and processed by means of special computer code. To obtain the discrimination parameter, areas $(Q)$ of slow and fast components were collected in a final file. Then the ratio for each event was calculated as follows: $R=Q_{\text {slow }} / Q_{\text {fast }}$. The $n-\gamma$ discrimination parameter FOM was determined from $Q_{\text {slow }} / Q_{\text {fast }}$ versus $Q_{\text {fast }}$ dependences as well as from the shape of events distribution over $R$. (Note that Figure of Merit $-\mathrm{FOM}=S /\left(\delta_{\text {gamma }}+\delta_{\text {neu- }}\right.$ tron), where $S$ - separation between gamma and neutron peaks, and $\delta_{\text {gamma }}$ and $\delta_{\text {neutron }}$ - are full width at half maximum of the corresponding peak [1]).

\section{Results and discussion}

Fig. 3 shows the decay curves obtained under irradiation of our scintillator by $\mathrm{Pu}$ 239 source alpha particles with $E_{\alpha}=$ $5.4 \mathrm{MeV}$ energy and by $\mathrm{Bi}-207$ source electrons with $E_{e}=0.975 \mathrm{MeV}$ energy. It is seen that part of the slow component of the alpha particles pulse is much greater than that of the electron pulse.

We measured $n-\gamma$ discrimination parameter FOM for PS with different additive con- 


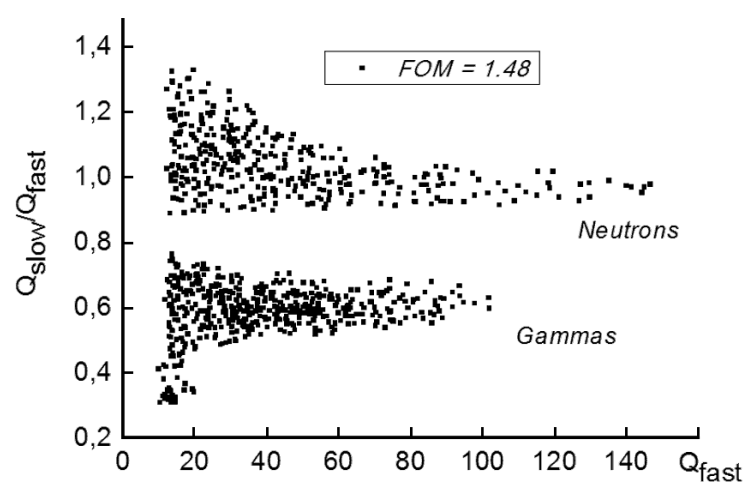

Fig. 4. Ratio $R=Q_{\text {slow }} / Q_{\text {fast }}$ vs $Q_{\text {fast }}$ for PS with $3.0 \%$ of Eu[DBM] $]_{3}$ Phen, $\mathbf{1 . 0} \%$ of DMDPA and $0.05 \%$ of L59. Excitation by plutonium-beryllium source Pu-239. The thickness of lead shield is $10 \mathrm{~mm}$. The registration threshold was set according to the scale corresponding to $E_{\text {threshold }}=250 \mathrm{keV}$.

tents. The best FOM was obtained for the sample consisting of $3.0 \% \mathrm{Eu}[\mathrm{DBM}]_{3}$ Phen, $1.0 \%$ DMDPA, and $0.05 \%$ L59. The dependence $R=Q_{\text {slow }} / Q_{\text {fast }}$ versus $Q_{\text {fast }}$ for $\mathrm{Pu}$-Ber neutron radiation is presented in Fig. 4. The registration threshold was set according to the scale corresponding to $E_{\text {threshold }}=250 \mathrm{keV}$. It is seen in Fig. 4 that the neutron and the gamma groups are clearly distinguished. When $R=Q_{\text {slow }} / Q_{\text {fast }}$ $>0.82$, mostly neutrons are observed and $\gamma$-quanta otherwise. The event distribution plotted according these experimental data over $Q_{\text {slow }} / Q_{\text {fast }}$ is presented in Fig. 5. This distribution was fit by two Gauss functions. The separation $S$ between the peaks was evaluated from the distance between the mean values of fitting Gauss functions, which leads to $\mathrm{FOM}=1.48$.

Decreasing the $\mathrm{Eu}[\mathrm{DBM}]_{3}$ Phen content to less than 2.5 wt. $\%$, at 1.0 wt. \% DMDPA concentration, reduces FOM to 1.03 because of the decreasing the slow component intensity. Increasing the $\mathrm{Eu}[\mathrm{DBM}]_{3}$ Phen content to more than 3.5 wt. $\%$, at 1.0 wt. $\%$ DMDPA concentration, also reduces FOM to 1.20 because of the decreasing transparency. Increasing the DMDPA content to more than 1.5 wt. $\%$, at $3.0 \% \mathrm{Eu}[\mathrm{DBM}]_{3}$ Phen concentration, leads to the worsening of $n / \gamma$ discrimination $(\mathrm{FOM}=1.23$ ) because of the decreasing transparency. Decreasing the DMDPA content to less than $0.7 \mathrm{wt}$. $\%$, at 3.0 wt. $\% \quad \mathrm{Eu}[\mathrm{DBM}]_{3}$ Phen concentration, leads to the worsening of $n / \gamma$ discrimina-

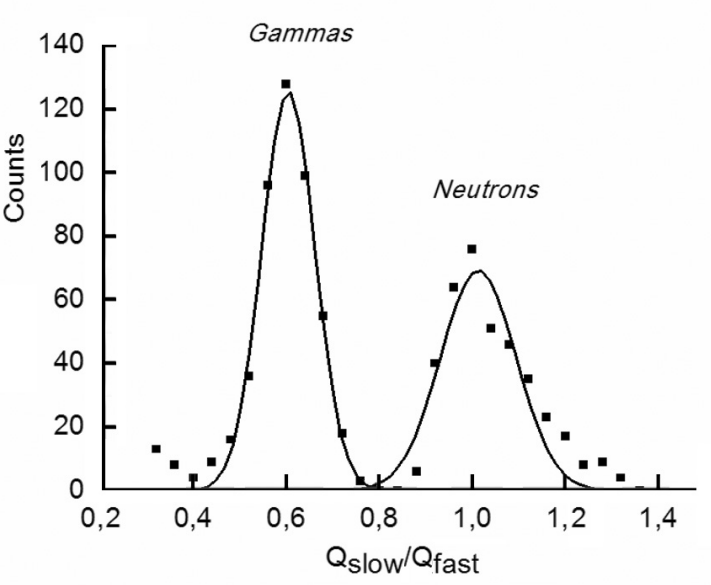

Fig. 5. Events number distribution over $R=$ $Q_{\text {slow }} / Q_{\text {fast }}$ for the sample with $3.0 \%$ of Eu[DBM $]_{3}$ Phen, $1.0 \%$ of DMDPA and $0.05 \%$ of L59. Solid line - fitting by a Gauss curve.

tion $(\mathrm{FOM}=1.21)$ because of decreasing the scintillating pulse slow component.

\section{Conclusion}

The PS of the new generation has been developed with efficient neutrons and gamma quanta PSD because of the direct transformation of the triplet excitation energy. With 3.0 wt. \% Eu[DBM $]_{3}$ Phen, 1.0 wt. $\%$ DMDPA, and 0.05 wt. \% L59 content, this PS provides the reliable PSD with the FOM of 1.48 .

\section{References}

1. N.Zaitseva et al., Nucl.Instr. Meth. Phys. Res. $A, 668,88$ (2012).

2. E.Bovet, P.Boschung, J.Rossel, Nucl. Instr. Meth. Phys. Res., 101, 315 (1972).

3. K.Peuckert, Nucl.Instr. Meth. Phys. Res.A, 17, 257 (1962).

4. W.Daenhick, R.Sherr, Rev.Sci.Instr., 32, 666 (1961).

5. J.H.Baxendale, M.Fiti, J.Chem.Soc. Faraday Trans., 2, 218 (1972);

6. I.H.Campbell, B.K.Crone, Appl. Phys. Lett., 90, 012117 (2007).

7. A.F.Adadurov, P.N.Zhmurin, V.N.Lebedev, V.V.Kovalenko, Appl. Rad. and Isot., 69, 1475 (2011).

8. A.F.Adadurov, P.N.Zhmurin, V.N.Lebedev, V.V.Kovalenko, Nucl. Instr. Meth. Phys. Res. $A, 621,354$ (2010).

9. J.B.Birks, The Theory and Practice of Scintillation Counting, Pergamon Press, New York (1964).

10. B.M.Krasovitskii, L.M.Afanasiadi, Preparative Chemistry of Organic Luminophores, Folio, Kharkov (1977) [in Russian]. 